\title{
Review on the Effect of Women Status in the Fisher and Rice Farmer Households on Family Food Security at Pangkep District, Indonesia
}

\author{
Suryawati Salam \\ Department of Social Economics, Faculty of Agriculture, 45 University of Makassar, \\ Indonesia \\ Email: s_salam200958@yahoo.com \\ Zulkifli Rasak \\ Department of Social Economics, Faculty of Agriculture, 45 University of Makassar, \\ Indonesia \\ Jamil Gunawi \\ Department of Social Economics, Faculty of Agriculture, 45 University of Makassar, \\ Indonesia \\ Aylee Christine \\ Department of Social Economics, Faculty of Agriculture, 45 University of Makassar, \\ Indonesia
}

Accepted: October 03, 2012 Published: November 12, 2012

Doi:10.5296/jsr.v3i2.2670 URL: http://dx.doi.org/10.5296/jsr.v3i2.2670

\begin{abstract}
This research reviews and analyzes the effect of women status in the household and its component on the food security of fisher and rice farmer households in two different villages, which are Bontomanai Village at coastal region and Taraweang Village at rice producer region, Labakkang Subdistrict, Pangkep District, South Sulawesi Province. Two hundreds of respondents are involved consisting 100 fisher households and 100 rice farmer households. Respondents are selected by simple random sampling. Multiple regression model is used to determine the factors affecting household food security. Of two household groups and using food range as the indicator of household food security, fisher household shows relatively better degree of food security than rice farmer household. Result of research indicates that women status is not having obvious effect on household food security although it has all conforming signs. Household income and household economic base have obvious effect on household food security.
\end{abstract}


Keywords: Gender, Fisher, Rice Farmer, Food Security, Pangkep

\section{Background}

The role played by women is significant in the economic development of a nation, especially at rural and agricultural sectors. Some researches show that in developing countries and in countries in the process of developing, women workers are the most important part of agricultural workers. Women play important role in all stages of food production, including in the food processing and food preparation. In some poor countries, where their economic rely a lot on agriculture, less than $60 \%$ of the total poor are women (Danida 2008).

Women participation in the production process put them in the important position to determine the nutrient status of household and to contribute the household income. For instance, helping to supply clean water for household and to prepare agricultural land is really describing the importance of woman in the agriculture. Gender balance in the growth and development of agriculture is important for the success of agriculture program, thus also helping to reduce poverty. Some factors, however, constrain the improvement of women status in the development, especially at place where tradition and culture are restrictive against women. Indeed, patriarchy ideology is always motivated by culture, religion sanction, and illiteracy reason, thus restraining strictly women freedom in choosing their method of social interaction. As a result, women contribution to the agriculture and other sector is very difficult to measure, especially when to calculate their economic performance.

According to Prakash (2003), women always experience discrimination where they are confined only to the reproduction role and they are excluded from their access to actual resource which actually increases their social and economical contribution to the community. Women role in agriculture sector, especially their contribution to the income and workforce, has been studied and analyzed. Some researchers, including Quisumbing et al. (1995), report that women play important role in securing the household food security. However, researches on individuals such as women, husband and children, are needed for detail analysis on the effect of women status on food security.

This current research attempts to review and to analyze the effect of women status in the household and its component on the household food security. Research is conducted on two communities with different economic base, which are fisher household and rice farmer household at Pangkep District, South Sulawesi Province.

\section{Research Methodology}

\subsection{Data Collection}

Research is conducted from January to February 2012 at Pangkep District, South Sulawesi Province. The consideration behind this research is that Pangkep District has potential in three dimensions, such as land, sea and mountain. Of 13 subdistricts, one subdistrict is selected 
purposively, which is Labakkang Subdistrict with land and sea potentials. Next, of 13 villages at Labakkang Subdistrict, two villages are selected purposively, which are Bontomanai Village in the coastal region and Taraweang Village representing rice production region. The sample of research is 100 fisher households and 100 rice farmer households. Therefore, the respondent total is 200 respondents who are selected randomly (through simple random sampling). The diversity of attributes is ensured to produce information representing real condition at research area.

\subsection{Data Analysis}

Data analysis is using unitary model approach, meaning that each household member is working simultaneously to maximize a function of utility. In general, food security model can be formulated as follows:

$F S_{t}=\alpha_{1}+\alpha_{2} W S_{1 . t}+\alpha_{3} W S_{3 \cdot t}+\alpha_{4} W S_{3 \cdot t}+\alpha_{5} H H_{t}+\alpha_{6} Y_{t}+\alpha_{7} D+\mu_{t}$

where, FS is food security of the household. Indicators used to measure food security are diversity or diet diversity (Smith and Subandoro 2007, Haddinott dan Yohannes, 2002). These indicators are estimated by calculating the number of food type or food group consumed by household where the survey is conducted. For analysis, respondent is interviewed to acknowledge household consumption for 7 days.

Women Status (WS) is measured based on the relative position of wife to husband. Three indicators are used to measure woman status (wife): (1) whether the wife works for cash income (WS1), measured by the ratio of cash income of wife to husband; (2) the ratio of age of wife to husband (WS2); and (3) the ratio of education of wife to husband (WS3). Woman status factor is included into the model is because some researches indicate that the increased women status relative to husband, in the social and economical aspects, is always increasing bargaining power of women and in turn, improving women control over the allocation of household resource. The increase of bargaining power of women correlates with food security (Guha-Khasnobis and Hazarika (2006), Handa (1996) and Schults (1990)). All variables of woman status are hypothesized as having obvious and positive effect on household food security. Other factors estimated to influence food security are the number of household member $(\mathrm{HH})$, household income $(\mathrm{Y})$, and dummy variables which act as the proxy for household economic base (D), where $\mathrm{D}=1$ for rice farmer household and $\mathrm{D}=0$ for fisher household. Household income and household economic base have obvious and positive effect on household food security. Meanwhile, number of household member will have obvious and negative effect on household food security. 


\section{Result and Discussion}

\subsection{The Profile of Rice Farmer and Fisher}

The information of household characteristic is needed to describe the actual condition of household before it is further analyzed to understand the degree of household food security. The characteristic of rice farmer and fisher households in the research area is shown in Table 1.

Concerning with age characteristic, the average of age of household head is more than wife, either at rice farmer or fisher households. The average of age difference between husband and wife is less than 6 years. The average of age of husband and wife at both groups is still remaining in the productive category of age for social and economical activities.

Furthermore, as viewed from education length, in average, household head has education background of elementary school. It is seen from the average of education length and education rate distribution. If compared to rice farmer household, the education length and education rate of fisher household is relatively better, either for husband or wife. Age and education are explaining the ability and pattern of household in the decision making.

Life experience is longer for husband than wife. The better education factor of husband implies to the ability of thinking and acting such that husband is usually dominating wife in the decision making. As revealed by Kishor (2000), these "setting indicator" factors (age and education) will set the different life experience of husband and wife, and thus, establish the different power or authority of the decision-making between husband and wife. For instance, education length, according to Kishor (1999), will facilitate someone to have understanding, interpretation, and action in the environment, and to have social contact with people outside the house.

Household access to the food is very influenced by household income. According to Suhardjo (1996), household income is used as an indicator for household food security because income is a main key for household to access for food. If understood from the average of income of both household groups, the average of income of rice farmer household is higher than fisher household. However, wife contribution to the income of fisher household is higher than rice farmer household. Household industry in the fisher household environment, such as marinated fish processing, allows fisher women to give greater contribution to household income. Table 1 shows that income contribution of wife to household is smaller than husband, either for rice farmer or fisher households. Smith et al. (2003) assert that the contribution of cash income to household income can be a source to increase authority or power in the relative decision making of wife relative to their husband. Some explanations are behind this. First, women contribution to household income is reflecting the economic freedom of women. Second, women contribution to household in come will increase their household status. And, three, the work owned by women will also improve the social contact of women to increase social capital of women, thus finally increasing women status relative to their husband (Kishor, 2000). Other household characteristics such as the number of household member, house condition and 
number of room, and house width, are not different much. In average, there are 4.28 heads in the rice farmer household and are 4.47 heads in the fisher household. The distribution of house condition or house type is evenly spread for permanent, semi permanent or non-permanent.

Table 1 The Characteristic of Rice Farmer and Fisher Households at Pangkep District, South Sulawesi Province, Year 2011

\begin{tabular}{|c|c|c|c|c|c|c|c|}
\hline \multirow[t]{2}{*}{$\begin{array}{l}\mathrm{N} \\
\mathrm{O}\end{array}$} & \multirow[t]{2}{*}{ Characteristic } & \multicolumn{2}{|c|}{$\begin{array}{l}\text { Taraweang Village } \\
\text { (Rice Farmer) }\end{array}$} & \multicolumn{4}{|c|}{$\begin{array}{l}\text { Bontomanai Village } \\
\text { (Fisher) }\end{array}$} \\
\hline & & Average & Min & Max & Average & $\begin{array}{l}\text { Minimu } \\
\mathrm{m}\end{array}$ & Maximum \\
\hline 1 & Age (years) & & & & & & \\
\hline & Husband & 43.06 & 20.00 & 67.00 & 41.77 & 25.00 & 70.00 \\
\hline & Wife & 37.53 & 18.00 & 60.00 & 35.32 & 21.00 & 60.00 \\
\hline 2 & $\begin{array}{l}\text { Education length } \\
\text { (years) }\end{array}$ & 7.19 & 0.00 & 17.00 & 7.35 & 0.00 & 12.00 \\
\hline & Husband & 6.35 & 0.00 & 18.00 & 6.59 & 0.00 & 17.00 \\
\hline 3 & $\begin{array}{l}\text { Wife } \\
\text { Education rate } \\
(\%)\end{array}$ & 0.92 & & & & & \\
\hline & Husband & 65.14 & & & 0.91 & & \\
\hline & a. $<$ Elementary & 24.77 & & & 60.91 & & \\
\hline & b. Elementary & 8.26 & & & 23.64 & & \\
\hline & c. Junior High & 0.92 & & & 14.55 & & \\
\hline & d. Senior High & & & & 0.00 & & \\
\hline & e. $>$ Senior High & 3.77 & & & & & \\
\hline & Wife & 70.75 & & & 8.26 & & \\
\hline & a. $<$ Elementary & 20.75 & & & 54.13 & & \\
\hline & b. Elementary & 3.77 & & & 28.44 & & \\
\hline & c. Junior High & 0.94 & & & 8.26 & & \\
\hline 4 & $\begin{array}{l}\text { d. Senior High } \\
\text { e. > Senior High }\end{array}$ & & & & 0.92 & & \\
\hline & Household & 822 & 0.00 & 750 & & 400 & 500 \\
\hline & income & 837.00 & 0.00 & 000.00 & 322 & 000.00 & 000.00 \\
\hline & (Rp/month) & 484 & & 000 & 606.00 & 0.00 & 000 \\
\hline 5 & $\begin{array}{l}\text { Husband } \\
\text { Wife }\end{array}$ & 234.00 & $\begin{array}{l}200 \\
000.00\end{array}$ & 000.00 & $\begin{array}{l}2 \quad 667 \\
100.00\end{array}$ & 600 & 000.00 \\
\hline 6 & Household & 307 & & 750 & & 000.00 & 500 \\
\hline & $\begin{array}{l}\text { Number } \\
\text { household }\end{array}$ & 072.00 & $\begin{array}{l}0.00 \\
2.00\end{array}$ & 000.00 & $\begin{array}{l}3 \quad 589 \\
317.00\end{array}$ & 1.00 & 000.00 \\
\hline & member & 4.28 & & 10.00 & & & 9.00 \\
\hline
\end{tabular}


House condition 28.44

37.61

8.00

4.47

$8 \quad(\%)$

33.94

12.00

21.62

Permanent

53.94

1.00

38.74

12.00

Semi permanent

2.37

$$
50.00
$$

39.64

1.00

120.00

Non permanent

2.37

House wide $\left(\mathrm{m}^{2}\right)$

5.00

46.82

5.00

Number of room

Source: Primary Data (processed, March, 2012)

\subsection{The Diversity of The Degree of Household Food Security}

This indicator is measured or counted based on the number of food or food group consumed (diet diversity) by each household where the survey is conducted. The average of diet diversity consumed by fisher household is better than rice farmer household, as shown in Table 2. The average of diet diversity consumed by fisher household is 4.71 , while that by rice farmer household is only 4.33 .

If classified based on household food security degree, the moderate and low degrees are relatively higher in the rice farmer household than fisher household. More than $87 \%$ of rice farmer households have moderate and low food security degrees. Meanwhile, $54 \%$ of fisher households have moderate and low food security degrees. The data, at least, inform that rice farmer household is relatively susceptible than fisher household based on the diet diversity consumed. If measured from household income which is reflecting food access, rice farmer household is more resistant to food susceptibility (Table 1) because they have higher household income average. This result indicates the less consistency of food diversity as the indicator. However, this finding needs deeper review.

Table 2 The Food Security Degree of Rice Farmer and Fisher Households at Taraweang Village and Bontomanai Village, Labakkang Subdistrict, Year 2011

\begin{tabular}{lll}
\hline Food Security & $\begin{array}{l}\text { Rice Farmer } \\
\text { (Taraweang Village) }\end{array}$ & $\begin{array}{l}\text { Fisher } \\
\text { (Bontomanai Village) }\end{array}$ \\
\hline The average of diet diversity consumed & $\begin{array}{l}4.33 \\
(0.92)\end{array}$ & $\begin{array}{l}4.71 \\
(1.03)\end{array}$ \\
Food security degree (\%)1 & & \\
High & 12.04 & 45.95 \\
Moderate & 22.22 & 35.14 \\
Low & 65.74 & 18.92 \\
Food security degree $(\%) 2$ & & \\
Susceptible $(<5.6)$ & 87.96 & 54.06 \\
Resistant $(>=5.6)$ & 12.04 & 18.92 \\
\hline
\end{tabular}

Note: 
1) based on Swindale and Bilinksy' classification (2005) in Smith and Subandoro (2007)

2) based on Smith and Subandoro (2007).

Number in bracket shows standard deviation

Rice farmer household tends to consume the farming outcome (subsistence). Therefore, the food in rice farmer household has relatively low diversity. Other reason is related to the market in the research area, especially in the rice production area, which is only opened once in a week. It is worsened by the lower diet diversity offered by market such that the food consumed by rice farmer is not varied much.

\subsection{The Effect of Women Status on Household Food Security}

The collinearity result between independent variables used in this research is not showing the presence of high collinearity $(r>0.8)$. It seems that multicollinearity is not a big deal in the model used in this research. Result of F-test indicates that all variables used in this model are simultaneously influencing household food security in the research area. It means that model is reliable to explain any variations occurred in the household food security. Result of step ways analysis shows that no single variable of women status is having obvious effect on women. The model used in this review is the preliminary model which is previously designed. Table 3 will present the result of multiple regression analysis over the determinant factor of food security in the rice farmer and fisher households. This table shows that factors influencing household food security, as measured in diet diversity, are income and household economic base. Because both are significant in trust rate of $99 \%$, these factors also have a sign matched with expectation or hypothesis. The variable of income, for instance, has positive sign, meaning that the increased household income will obviously increase the degree of household food security. This finding is understandable because the increased household income is also related to the increased access of household to the food, which is in turn, reflecting the increased status of household food security. Household economic base, either in rice farmer or fisher households, also has obvious but negative effect. The negative sign indicates that household with fisher economic base tends to have food susceptibility than rice farmer household. It seems in contrast with the description data about the distribution of rice farmer and fisher households based on food security degree (Table 3). The number of fisher household with food susceptibility is less than the number of rice farmer household with similar case.

The number of household member which reflects household size is not having a significant effect, and without the compatible sign (negative) on the degree of household food security degree. Theoretically, this finding is in contrast once again because the increased number of household member will reduce food security degree. Indeed, this finding shall be interpreted cautiously because it may be possible to find inaccuracy of using diet diversity indicator as food security indicator. Household tendency to consume similar food type over time is obvious because of the limited diet diversity offered by market in research area. Therefore, the variation of food type consumed is not much. 


\section{Ml Macrothink}

Journal of Sociological Research

ISSN 1948-5468

2012, Vol. 3, No. 2

Women status as the research focus does not have great significance in every trust degree. Three indicators that are used show that women status relative to husband is not obviously influencing household food security degree. However, if seen from the signs of three indicators, women status has a compatible sign, which is positive. The positive sign indicates that the higher women status tends to increase household food security degree. An explanation of this is that the education rate tends to relate with the ability to obtain information and to adopt food knowledge. The higher education rate of household head will facilitate them to adopt food and nutrient knowledge through the published media available in their environment.

Table 3 The Analysis of Multiple Regression on The Determinant Factor of Food Security of Rice Farmer and Fisher Households at Taraweang and Bontomanai Villages, Labakkang Subdistrict, Year 2011

\begin{tabular}{ll}
\hline Independent Variable & Coefficient of Regression \\
\hline Constant & 4.7138 \\
& $(0.3838)$ \\
Household income (Y) & $0.80423 \mathrm{E}-7 * * *$ \\
& $(0.2672 \mathrm{E}-7)$ \\
Household member (HH) & 0.01296 \\
& $(0.04655)$ \\
Women status & 0.26618 \\
& $(0.1976)$ \\
Ratio of cash income of wife to husband (WS1) & 0.30588 \\
& $(0.4098)$ \\
Ratio of age of wife to husband (WS2) & 0.11814 \\
& $(0.1531)$ \\
Ratio of education rate of wife to husband (WS3) & 0.11814 \\
& $(0.1531)$ \\
Economic base (D) & $-0.45542 * * *$ \\
& $(0.1432)$ \\
F-count & $3.497 * * *$ \\
R2 & 0.897 \\
\hline
\end{tabular}

Notes: *** significant at trust degree $99 \%$

Number in bracket is error standard

\section{Conclusion}

This research examines the diet diversity consumed by household as the indicator of household food security. As food security indicator, this approach is the easiest because it can be used fast and easily to categorize the household food security status. Result of analysis shows that food security degree of fisher household is better than rice farmer household. The number of household member does not have obvious effect. Research also shows that three variables as 


\section{Macrothink}

Journal of Sociological Research

ISSN 1948-5468

2012, Vol. 3, No. 2

the indicator of women status relative to husband are not influencing the household food security status.

\section{Acknowledgment}

The great thanks are given to the Rector of Universitas 45 Makassar and The Head of Research and Community Work Institution of Universitas 45 Makassar for the financial support in this research. Great appreciation is also extended to the community and the government of Pangkep District for the facility and cooperation during the research.

\section{References}

Danida. 2008. Gender Equality in Agriculture. Ministry of Foreign Affair of Denmark. Denmark.

Guha-Khasnobis, Basudeb and Hazarika Gautam. 2006. Women's Status and Children's Food Security in Pakistan. Discussion Paper No.2006/03. United Nations University WIDER. Helsinki.

Kishor, S. 2000. Empowerment of Women In Egypt And Links to Survival And Helath of Their Infants. In Presser H. and G Sen (Ed.). Women's Empowerment And Demographic Processes. Oxford University Press.

Prakash, Daman. 2003. Rural Women, Food Security and Agricultural Cooperatives. Rural Development and Management Centre 'The Saryu', J-102 Kalkaji, New Delhi 110019. India. February 2003. New Delhi.

Quisumbing, Agnes R. and J. Maluccio. 2003. Resources at Marriage and Intrahousehold Allocation: Evidence from Bangladesh, Ethiopia, Indonesian, and South Africa. Oxford

Smith, Lisa C. and Ali Subandoro. 2007. Measuring Food Security Using Household Expenditure Surveys. International Food Policy Reseacrh Institute. Washington D.C.

Suhardjo. 1996. Framework Definition and Household Food Security. Paper presented at the Workshop on Household Food Security. Yogyakarta. 26 to 30 May 1996. 